\title{
明治宮殿の造営過程に見る木造和風の表向き建物の系譜とその意匠的特徵 THE CHARACTERISTICS OF THE JAPANESE-STYLE DESIGN CREATED IN THE MEIJI PALACE'S BUILDING PROJECT
}

\author{
山、崎鯛介* \\ Taisuke YAMAZAKI
}

\begin{abstract}
This paper shows that the history of the Meiji Palace's building project should be interprited as a history of developping a traditional Japanese-style design into a modern Japanese-style design adaptable to the western style ceremonial space that had the higher-raised ceiling and the westernornamented walling. To show the traditional formality of the Palace, the Kyoto Palace's designs (the coved and coffered ceiling and the hinged shutters) were often quoted in the project. Finally these traditional designs were only applied to the private audience room, and in the other grandiose ceremonial space, these traditional designs were adapted taking care to its western interior.
\end{abstract}

Keywords : the Meiji Palace, Modern Japanese-style, the Kyoto Palace, tradition 明治宮殿、近代和風、京都御所、伝統

\section{1. 緒言}

明治 21 年に木造和風で建設された明治宮殿（正式には「皇居宮殿」） の意匠的特徴としては、表宮殿に見られる立式対応・和洋折哀の室内 意匠がよく知られている。この床を立式対応としながら、壁面や天井 意匠に柱・長押や格天井などの和風意匠を用いた意匠形式について は、その後、日本銀行本店（明治 29 年）の貴賓室や国会議事堂（昭 和 11 年) の便殿などにも用いられたことから、少なくとも後世にお いては建物の用途や構造形式に関係なく「格の高い接客空間」を表現 しうる室内意匠の形式の一つとして認識されていたと考えられる。

明治宮殿の和風意匠については、こうした後世の建築に与えた影響 が指摘される一方で、それ自体の表現意図、すなわち建設時において 設計者が何を表現するためにこうした和風意匠を用いたかという点 や、そうした意匠形式がどのような経緯を経て創出されたかという点 については、これまであまり論じられていない。表宮殿の和風意匠 は、近代的な立式の儀礼空間に「伝統」の表現を試みたものと考えら れるが、そこで何を「伝統」として示すかは「近代の宮殿」としての あり方を決定する際の重要な基準の一つであり、またその表現手法に ついては、建設時期の早さゆえに前例も少なく、設計過程においては さまざまな形で検討が繰り返されたと考えられる。そこで本研究で は、明治宮殿に用いられた和風意匠に注目し、竣功建物とともに造営
過程において示された和風意匠も含めて考察することで、そうした和 風意匠がどのような意図を示したものであるか、またその手法がどの ような経緯を経て形成されたものであるかについて明らかにした。

明治宮殿の造営過程については、小野木重勝博士の2つの論文「明 治宮殿」(博物館明治村編『明治宮殿の杉戸絵』平成 3 年）と『明治 洋風宮廷建築』(相模書房、昭和 58 年)に詳しい1)が、いずれも造営 過程は洋風組積造の計画案を中心に描かれており、木造和風の計画案 については、赤坂の洋風謁見所・会食堂移築計画の中止を受けて計画 された明治 14 年の木造和風宮殿計画と、山里正殿計画の中止を受け て明治16年以降に計画された実施過程の経緯が紹介されるに留まり、 計画案の内容にはあまり触れられていない。そこで本研究の方法とし て、まず造営過程で断続的に計画された木造和風の計画案について、 できるだけ史料を広範に蒐集してその具体的特徴を明らかにし、その 上でそれらの関係について考察することで、明治宮殿の造営過程を 「木造和風宮殿の形成過程」として捉え直すこととした。また、和風 意匠に示された「伝統」の意味を考察するため、その意匠的特幑を京 都御所の建物と比較した。京都御所は「木造和風宮殿」として明治宮 殿に先立つほとんど唯一の事例であるとともに、明治天皇が幼少時を 過こしたことからも、設計に際してモデルとして参考にされた可能性 が高く、また「近世の御所」と「近代の宮殿」の和風意匠の用い方を

\footnotetext{
$*$ 東京工業大学大学院理工学研究科 助手・工修 
比較することで、伝統的な日本建築の和風意匠と近代的な空間特性に 配慮した和風意匠との区別が明確になると考えられるからである。

既往研究では、明治宮殿の和風意匠について、造営計画全体を通し てその形成過程や表現意図を考察したものは見られない。小野木重勝 『近代和風宮廷建築における和洋折表技法に関する研究』(昭和 62 年 度科学研究費補助金 [一般研究 C] 研究成果報告書) では、明治 14 年の計画案が表宮殿・奥宮殿をともに木造和風で建設することに決定 した最初の計画案と位置づけられ、その1月案と京都御所との平面形 式の類似性を指摘している（p.7）が、その具体的な設計内容や意匠 的特徴については触れていない。稲葉信子『木子清敬と明治 20 年代 の日本建築学に関する研究』(東京工業大学博士論文、平成元年)で は、主任技師の一人である木子清敬の経歴から、「設計にあたっては、 京都御所や大宮御所などが参考にされたものと考えられる」(p.48) と指摘している。赤坂仮皇居会食所との比較や設計技術者を介した考 察は、明治宮殿の和風意匠を理解するにあたって重要な視点と考えら れるが、同書ではそれらについて具体的に検証するまでには至ってお らず、また作業の余地を残していると考えられる。設計技術者につい ては、小野木重勝『明治洋風宮廷建築』第七章第三節「技術者構成と 技術伝承」において、皇居造営に関与した技術者の経歷が明らかにさ れ、藤岡洋保・稲葉信子・斎藤雅子「東京都立中央図書館木子文庫所 收の明治宮殿設計図書に関する研究」(『日本建築学会計画系論文報告 集』第431号、1992）では、実際の設計過程における木子清敬の関わ り方が考察されたが、木子清敬も含めた個々の設計技術者が近代的な 和風意匠の㓱出過程でどのような役割を果たしたかについては、まだ 不明な点が多いと考えられる。本稿では、これら先行研究を踏まえ、 設計者と設計内容の具体的な関係について考察を加えた。

なお、拙稿「明治宮殿の建設経緯に見る表宮殿の設計経緯」(『日本 建築学会計画系論文集』第 572 号、pp.159-166、2003 年 10月)では、 明治宮殿の建設過程で行われた表宮殿の設計変更について、その経緯 と内容を明らかにし、また拙稿「明治宮殿の設計内容に見る儀礼空間 の意匠的特徴」(『日本建築学会計画系論文集』第 578号、pp.169-176、 2004 年 4 月）では、表宮殿の意匠的特徴を平面計画や用途との関係 から明らかにした。本稿の第四章では、これらの研究成果に基づき、 実施過程における表宮殿の和風意匠に見られる特徵を考察した。

史料として、明治 17 年以降の実施過程については、宮内庁所蔵『皇 居造営録』(皇居御造営事務局、明治 9 年 23 年) や『皇居御造営誌』 (内匠寮、明治 25 年)、および東京都立中央図書館木子文庫所蔵の明 治宮殿関係史料を主に用いて検討した。それ以前の計画案について は、木子文庫所蔵の図面史料や宮中関係者の日記、『明治天皇紀』な どをできる限り蒐集・精読して知見を得るように努めた。

\section{2. 明治 14 年に計画された「紫宸殿」風の謁見所}

小野木博士は、明治14年に計画された木造和風の計画案について、 主に構造上の理由から「木造」で計画された点に注目しているが、な せ「和風」で建設されたかという意匠上の問題については触れていな い。本章では、この時期の計画案について、その内容と経緯をできる だけ明らかにするとともに時代背景も含めて考察することで、なせここ の時期に宮殿が「和風」で計画されたかについて論じた。

この時期の木造和風の計画案としては、宮内庁所蔵『皇居御造営編 纂下調図』(以下『下調図』)に、京都御所の調查（明治 13 年 11 月 17
日）直後に作成された明治 14 年 1 月案（第 24 号、以下「初期案」)、 敷地境界などを考慮して初期案に修正を加えた ${ }^{21}$ 同年 4 月 11 日作成 の「天覧図」(第 26 号)、天覧後に明治天皇の意向を受けて修正を加 えた「修正案」(第27号)の平面図が収録されている。このうち「天 覧図」について見ると、謁見所、饗宴所、内謁見所、控所などの主要 建物は敷地南側に配され、北側には宮内省関係の諸室を配し、中庭に 共用のアプローチ空間を確保する配置構成が取られている(図1)。主 要建物の平面については、謁見所と内謁見所には京都御所の「紫宸 殿」や「小御所」とほぼ同じ規模・平面形式が用いられ、会食所と控 所はいずれも大空間の建物として描かれている3)。これらの建物は、 天覧後の修正によって内謁見所が御学問所との 2 階建てに変更され、 2 室あった控所が 1 室にまとめられたが、それ以外は天覧を経てほぼ そのまま承認されたと『皇居御造営誌』には記されている。

これらの建物は、まず「朝儀」のための場として計画されたと考え られる。『皇居造営録丹所収「會食所及溜ノ間人貝調方ノ儀宮内書記 官往復」 ${ }^{4)}$ には、「会食堂」と「控所」を使用する者の身分と人数が 記されているが、ここで「会食堂」は、親王、大臣参議、各国公使、 勅任官、爵香間詰の合計 156 人が使用すると算出され、また「控所」 は、上記の身分の者は夫人同伴で、その他に「武官奏任六等以上」(147 人)、「文官奏任并警視補」(415人) など、合計 2356 人が使用すると 算出されている。明治時代の朝儀は、明治 14 年に大幅に変更され、新 年拝賀には欧米風の夫人同伴形式が導入され、三大節賜宴（新年宴 会、紀元節晹宴、天長節賜宴）には外国公使が招待されるようになっ た がが、上記史料に記された招待客の身分は、こうした当帱の朝儀 の制度とほほ一致しており、上記史料の「会食堂」は三大節賜宴を、 「控所」は新年拝賀をそれそれ想定して、人数を算出したものであっ たと考えられる。

一方、これらの計画案では「国賓接待」あ）行うことは想定されて いなかったと考えられ、ここではボアンビル設計の洋風謁見所・会食 堂に見られた「転球所」や「喫茶室」など、外国賓客の謁見・饗応の ための諸室》が設けられていない。これは計画の前提として、外国 賓客の謁見·饗応施設を別途赤坂仮皇居内に石造で建設することが想 定されたためと考えられ、このことは、洋風謁見所の移筑中止が決定 された際の、「而シテ前條石造謁見所ノ議八右旧西丸皇居竣功赤阪假 皇居内太政官其他諸建物取払ノ後右御構内二於テ恰好ノ場所御撰定御

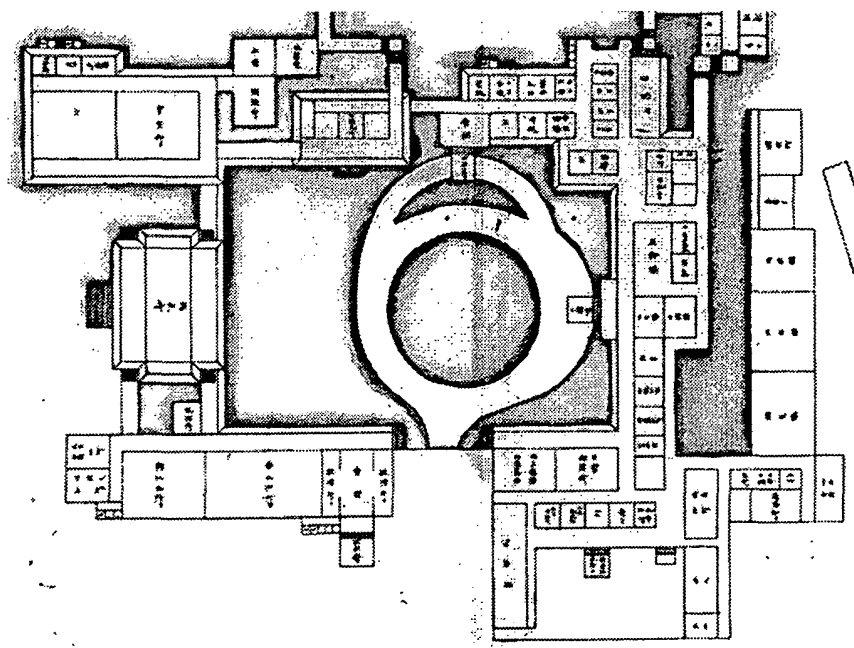

図1. 明治 14 年 4 月の木造和風宮殿計画「天覧図」(宮内庁所藏『皇居御造営 編萫下調図』所収・部分、方位は上方が西（山里）を示す） 
建築相成候テ可然卜存候」 ${ }^{8)}$ との『皇居御造営誌』の記述に椝える。 このように、この時期の木造和風の計画案は、宮殿の用途を「宮中儀 式」に特化して計画されたものであったと考えられる。

これら計画案に示された個々の建物の意匠についてはほとんど不明 であるが、「紫宸殿」風の謁見所については、工部少輔・吉井友実の 日記『三盽日記』 ${ }^{9}$ に、紫宸殿御模様 Э其嫿御用相成度申出則千評 議ス」(明治 13 年 11 月 17 日条) とあり、また後に計画案が批判され た際には、「且ツ紫宸殿ノ如キハ四方蔽障ナキヨ以テ寒時ノ禮典行ハ ル可力ラス到底時勢不相當ナル可キカノコト」10) と指摘されたこと から見て、平面形式だけでなく建物の構造や建具についても京都御所 の紫宸殿とかなり似たものが計画されていたと考えられる。なぜこう した「紫宸殿」風の謁見所が計画されたかは不明であるが、その理由 の一つとして、「即位の礼」などの皇位継承儀礼を謁見所において行 うことが想定された可能性が考えられる。皇位継承制度については、 岩倉具視を中心に明治 11 年頃から検討され始めたことが『岩倉公実 記』などから知られるが11)、それと並行して、「即位の礼」や立后・ 立太子の礼など皇位継承に関する儀礼の形式についても、京都御所を 保存し、そこで古式に則って行うことが明治天皇や宮中関係者によっ て提案されたことが知られている12)。この件は、最終的に「即位、大 曾會、立后ノ三禮八國家至重ノ大典ナレハ平安京ノ宮闕二於テ古式ノ 如ク執行セラル、モノト定ムヘシ」 ${ }^{13)}$ として、京都御所で挙行する ことが明治 16 年 4 月 26 日に決定するが、京都御所での挙行が不可能 であった場合には、皇居において儀式を行うことも当然想定されたと 考えられることから、古式の「即位の礼」を想定して「紫宸殿」風の 謁見所が計画されたという見方も、可能性としてはあり得る。

「修正案」では、謁見所に「紫宸殿」と記された他、内謁見所は 2 階建てに変更されたにもかかわらず「小御所」と記されるなど、建物 の呼称に御所風の名称が用いられた。こうした呼称は、吉井友実の考 案であることが『三峰日記』(明治 14 年 4 月 23 日条) から知られ、そ こでは京都御所には存在しない会食所や控所についても、「豊楽殿」 (会食所).や「斎集殿」(控所)と、復古的な呼称を用いることが提案 されている。こうした復古的なイメージの提案は、当時の宮中関係者 の関心を反映したものであったと考えられ、例えば柳原前光は、「魯・ 墺・孛皆君権熾盛ノ國ナリ、朝儀中頗ル旧格 7 墨守シ、現世不似合ノ 事ヨ行フ、蓋シ帝王国八皆慣習ヨリ成立ツモノ故、従テ儀式モ旧 7 守 ルニ似タリ（中略）故二我朝廷モ、祭祀ノ如キハ独有ノ禮ナレバ、頗 ル旧観习保存スル盛禮习存シ置候コト可然存候」 ${ }^{14)}$ と、西洋諸国も 各国固有の慣習に則って「朝儀」を行っており、日本も宮中儀礼を古 式で行うべきであると主張している。この時期の皇居造営の主任は、 工部少輔の吉井友実であったと考えられる1s) が、吉井は同時に天皇 側近の侍補でもあったことから、計画案には天皇や宮中関係者のこう した意向が入る余地も多分にあったと考えられる。

宮中関係者に見られるこうした復古的な宮中儀式への関心の高まり の背景には、この頃に宮中儀礼が急速に洋風化されたことへの反感も あったと考えられる。宮中儀式の洋風化は、条約改正予議会 ${ }^{16)}$ の開 催を控えた明治 13 年頃から、外務卿・井上馨によって「観菊会」「観 桜会」などイギリス風の園遊会の開催や、新年拝賀への夫人参加、三

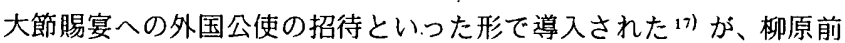
光や佐佐木高行などの宮中関係者の日記・書簡18) からは、こうした 一連の洋風化に対して宮中関係者の多くが反感を持っていた様子を知
ることができる。井上蔡はまた、儀礼形式の洋風化だけでなく、皇居 造営計画においては洋風組積造の建設も推進したと考えられ、それは 『三峰日記』に「工部卿卜共二御前二伺候御造営二付テハ御入費二無 御構堅牢ヨ主卜被遊度旨井上ヨリ言上二及七御承諾被遊候事」(明治 12 年 7 月 22 日条) と、工部卿の在任期間（明治 11 年 7月〜明治 12 年 9月）にボアンビル設計の赤坂謁見所・会食堂建物の移築を推進した ことを示す記述が見られることや、山里正殿計画においては「皇居造 営局被設置候事二相成、総裁は條公、副総裁は野生被仰付候段、全く 尊台之御配虑よりして斯く相運び候段、不堪銘感之至、早速右御吹聴 二罷出候義二御座候。扨又此上二も猶尊台之インフリユーエンスを仰 度事は、局中之諸役貝中二就キ、工部より出居候平岡氏並二會計長谷 川氏は、是非共御造営局専務二被仰付度之一事二而候」19）と、洋風 正殿計画を主導した榎本武揚を皇居造営事務局副総裁に推萀したこと を示す書簡が残されていることなどに䇲える。

以上のことから、この時期に計画された木造和風宮殿は、宮殿の用 途を「宮中儀式」に特化し、そこで復古的な宮中儀式を行うことを前 提に計画されたものであったと考えられる。これは、その前後に計画 された洋風謁見所の計画が、あくまで皇居で洋風の「国賓接待」を行 うごとを中心に計画されたものであったのに対し、「国賓接待」は赤 坂の離宮で行えば良いとする宮中関係者の考え方を主に反映したもの であったといえる。このように、造営計画の初期において計画が二転 三転した理由には、従来知られてきた構造形式や様式の問題ととも に、「近代の宮殿」の用途に見られる二面性、すなわち「伝統的な宮 中儀式」と「洋風の国賓接待」のいずれを優先するかを巡って、「宮 中」と新政府が対立していたことの影響もあったと考えられる。

\section{3. 吹上宮殿に計画された「小御所」風の内謁見所}

明治 14 年 4 月に天覧に供された木造和風宮殿の計画は 5 月に入っ て急遽中止され、新たに洋風組積造の山里正殿と木造和風の吹上宮殿 からなる計画が立案された。山里正殿については、小野木博士の研究 によってその詳細が既に明らかにされているか、「奥向宮殿」と位置 づけられた吹上宮殿の内容については、これまでほとんど知られてい ない。しかし、木子文庫には吹上に計画された内謁見所卸学問所、 御車寄などの図面が数多く残されており、吹上宮殿にもそうした「表 向き」の施設が木造和風で計画されていたことが知られる。そこで本 章では、これら吹上宮殿に計画された「表向き」の木造和風建物につ いて、その設計過程と設計内容をできるだけ明らかにするとともに、 その意匠をほぼ同時期に建設された赤坂仮皇居会食所（明治 14 年 10 月竣エ)と比較することで、和風意匠の用い方に「宮殿」としての「格 式」を表現しようとする意図が見られることを論じた。

吹上宮殿の計画案については、『下調図』に明治 14 年 7 月 11 日か ら明治 15 年 12 月 27 日にかけて作成された 13 種類の平面図 ${ }^{20)}$ が収 録された他、宮内庁畫陵部には「明治十五年十二月廿七日調整」と記 された吹上宮殿の全体平面図が所蔵されており、平面計画の変遷につ いて知ることができる。明治 16 年 1 月 13 日には、皇居御造営事務局 が工事監理を主とした体制へと改組された ${ }^{21)}$ ，と見られることから、 明治 15 年 12 月 27 日案は、吹上宮殿計画における「最終案」と見て 良いと考えられるか、この「最終案」を見ると、山里正殿との連絡橋 に近い最も「表向き」と考えられる敷地東側に、左右相称形の御車寄 と大面積の内謁見所が設けられたことがわかる（図2）。内謁見所は、 
外国公使や臣下との内謁見を行う場所であることから、宮殿には不可 欠の施設と考えられるが、山里正殿にはそれに相当する部屋が計画さ れておらず、ここでは山里正殿の機能を補う形でこれら表向きの施設 が吹上宮殿に計画されたと考えられる。

また設計過程について見ると、これらの建物は吹上宮殿の計画当初 には計画されておらず、明治 15 年 6 月以降に計画されるようになっ たことが『下調図』からわかる。それ以前には、聖上常御殿に隣接し て計画された「御三間」 $\left.{ }^{22}\right)$ が内謁見用の建物に充てられたと考えら れ、御車寄についても、当初は御学問所に付属する簡便な形のものと して、また明治 15 年 4 月・6 月案では一列型の独立建物として聖上常 御殿と御学問所の中間の位置に計画されたことがわかる。いすれもそ の配置を見る限り、公的な内謁見には不都合と考えられることから、 主に天皇の私的な用途を想定して計画されたと考えられる。御車寄 は、最終的に記念性の強い左右相称形の平面で計画されたか、これは 明治 14 年 11 月 24 日に制定された「御車寄昇降規定」において、「御 車寄」を天皇以下の皇族や外国公使が使用するものと定め、日常的に 臣下が使用する「通常車寄」と区別するようになった 23)ことを受け て、「御車寄」の立面に「格式」を表現したものであったと見ること ができる。このように、吹上宮殿に計画された内謁見所と御車寄に は、実際に使用することを想定して計画されたと考えられる節が見ら れるか、そうした傾向は、これらの建物か山里正殿計画が確定 (明治 15 年 3 月 17 日）し、その事業組織である「皇居造営事務局」が設置 （明治 15 年 5 月 27 日）された後に計画されたことにも窥える。

次に、内謁見所の設計内容について詳しく見ると、内謁見所が大面 樌で計画されるようになったのは、明治 15 年 10 月以降であったこと が『下調図』からわかる。木子文庫には、この大面積の内謁見所に関 する平面図・立面図・矩計図・屋根伏図・小屋組図が残されており24)、 これらを用いて内謁見所の規模と意匠について表 1 によめ、それを ほぼ同時期に建設された赤坂仮皇居会食所と比較した ${ }^{25}$ 。両者を比較 すると、平面については梁間と桁行きの比率が異なるものの、床面積 は 56 坪〜 58 坪とほぼ等しく、内法高や天井高についてもほぼ同じで あることから、内部空間がほぼ同じ規模で計画されたことがわかる。 一方、意匠については違いが見られ、吹上宮殿の内謁見所には赤坂仮 皇居会食所に見られない「蔀戸」や「折上小組格天井」などが用いら れ、また北西部に矩折れで設けられた「御椽座敷」の天井には「化粧 屋根裏」が用いられた 26)。この「蔀戸」や「折上小組格天井小「化粧 屋根裏」は、京都御所の紫宸殿や小御所などに見られ、近世武家の表 向き御殿にはあまり見られないことから、「御所風」の意匠と見て良 いと思加れ。吹上宮殿の内謁見所と赤坂仮皇居会食所は、その時期
と規模がほぼ同じであることに加え、いずれも設計に木子清敬が深く 関与したと考えられる27ことから、こうした意匠の用い方の違いは、 「御所風」の意匠を正式な「宮殿」に適用することで、「仮皇居」より も格の高い意匠表現を試みたものであったと考えられる。そして、こ うした御所風の意匠を適用した結果、内謁見所の外観意匠は京都御所 の「小御所」とよく似たものとなったことがわかる（図 3)。

このように、吹上宮殿の内謁見所は、大面積で「小御所」風の意匠 を持つ建物として計画された。この理由としては、内謁見以外に「朝 儀」を行うことが想定されたためと考えられ、それは赤坂仮皇居にお いては三大節賜宴が新筑の会食所で行われていたのに対し、吹上宮殿 にはそれに相当する規模の建物が他に見あたらないこと、また睗宴に 先立って行われる拝謁については、明治 14 年以降、「但し、今年より 各國公使を招請したまふ、又祝宴を小御所代に開きたまふに先立ち、 御座所に於て、親王侍立の下に大臣・参議・外務卿・各國公使に謁を 賜ひ、親王及び大臣以下を従へて小御所代に出御あらせらる」28）と、 身分の高い者は御座所で天皇に择謁し、その後一緒に会食所に出御す る形式に改められており、これを山里正殿で行うには距離が遠く、聖 上常御殿や御学問所と近接する内謁見所で行う方が適切と考えられる ことなどから推察される。三大節賜宴は立式・洋装で行われたが、そ の内容は一貫して、勅語あり、和食寔餐、皇后・婦人不参加といった 伝統的な形式であったことが『明治天皇紀』などから知られ、内謁見 所に用いられた「御所風」の意匠はまた、こうした「朝儀」の伝統的 な内容にも配慮して計画されたと考えられる。

以上のように、吹上宮殿には「小御所」風の内謁見所が、臣下や外 国公使との内謁見だけでなく、新年拝賀や三大節賜宴などの伝統的な 「朝儀」も行う場として計画されたと考えられる。これは「国賓接待」 に特化した山里正殿に不足する施設を実施を前提に吹上宮殿に計画し たものと見ることができ、そうした現実的な点において、いずれか一

\section{表 1. 吹上宮殿計画「内謁見所」と赤坂仮皇居会食所との比較}

\begin{tabular}{|c|c|c|c|}
\hline & & 吹上宮殿 - 内謁見所 & 赤坂仮皇居·会食所 \\
\hline \multirow{3}{*}{ 空间の規模 } & 平面形状 (粱間 $\times$ 桁行) & $\begin{array}{c}35.75 \text { 尺 } \times 58.5 \text { 尺 } \\
=58 \text { 坪 }\end{array}$ & $\begin{array}{c}28.35 \text { 尺 } \times 72 \text { 尺 } \\
=56.7 \text { 坪 }\end{array}$ \\
\hline & 天并意(迢稳下端) & $13.94 R$ & $1426 \Omega$ \\
\hline & -内法高（無目下端） & 7尽 & 6.98 \\
\hline \multirow{2}{*}{ 楧造形式 } & 柱太态 & 6寸魚 & 6.6 角 \\
\hline & 小屡組 & 上ラス & 和小屋 \\
\hline \multirow{4}{*}{ 室内意匠 } & 庶茌上 & 丕琞 (板張下地) & 娍綮敷き（掝板下地） \\
\hline & ...建具 & 被 盟障子 & 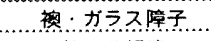 \\
\hline & 天井形式 & 折上小組格天刑 & . . 格天井板違 . . . \\
\hline & 外周建具. & $\ldots \ldots \ldots \ldots . .$. & ‥建薣戸 \\
\hline \multirow[t]{2}{*}{ 外钼意压 } & 㞔根 & 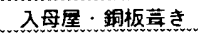 & 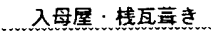 \\
\hline & 高相の有無 & 有 & 無 \\
\hline
\end{tabular}

*12月案は「折上小組格天井小10月案は「化粧屋根裹」と記されている。

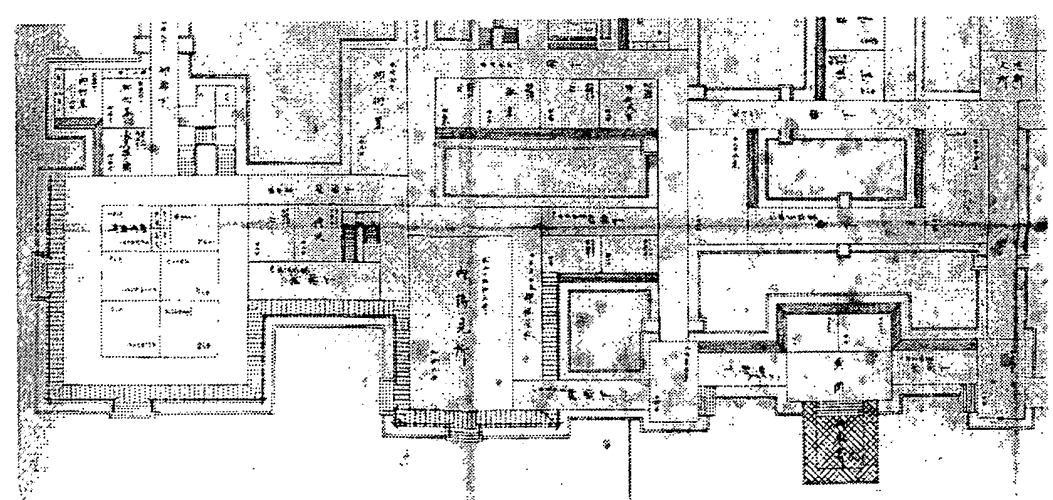

图2

吹上宮殿計画「最終案」平面図 (明治 15 年 12 月 27 日、宮内庁所藏・部分)

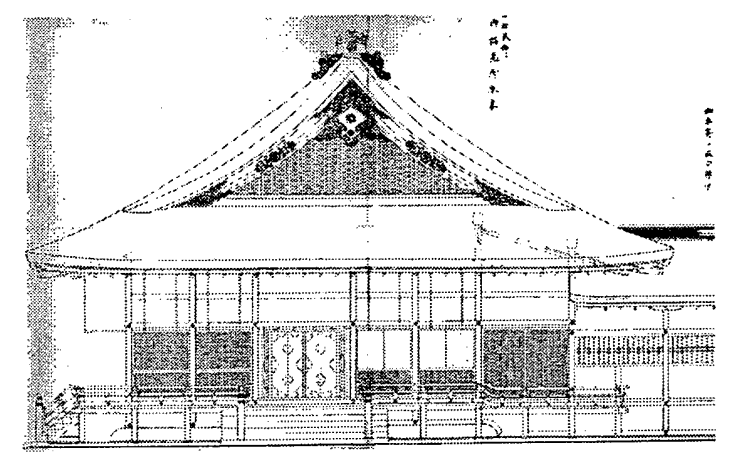

图3. 吹上宮殿計画「内謁見所」東立面図（明治 15 年 10 月 12 月頃、東京都立中央図書館 · 木子文庫所収） 
方に特化することを主張して計画変更を繰り返した明治 13 年〜 14 年 の計画案よりも、造営計画がより具体的な段階に進展したことを示し ていると考えられる。

\section{4. 建設過程の設計変更における近代的な和風意匠の考案}

山里正殿・吹上宮殿計画はその後、明治 16 年 4 月 23 日に中止が決 定し、同年 7 月に「木製假皇居」として全て木造和風で建設すること に決定した。中止決定に先立つ4月14日には、宮内卿・徳大寺実則 によって右謁見所ノ儀八元来謁見所ノミノ構造ニシテ皇居正殿二可 充儀二無之就テハ廉々不都合ノ場所不少到底完全ノ物二無之候」との 上申文 ${ }^{29)}$ が出されたが、これは第二章・第三章において見てきた「国 賓接待」と「宮中儀式」との関係を踏まえると、山里正殿が伝統的な 「朝儀」を行うのに不向きであることを批判したものと読むことがで きる。明治 17 年 4 月以降の設計過程については、拙稿「明治宮殿の 建設経緯に見る表宮殿の設計経緯」(先揭) において、洋風の「宮中 夜会」を念頭に、表宮殿の主要建物に対して天井高の拡大や室内意匠 の洋風化といった設計変更が加えられたことを明らかにしたが、う した壮麗な内部空間においては、伝統的な日本建築に用いられた和風 意匠をそのまま適用することは難しく、大空間・和洋折表といった近 代的な空間特性に配慮しつつ、新しい和風意匠を考案することが求め られたと考えられる。そこで本章では、建設過程で加えられた「天井 高の拡大」と「室内意匠の洋風化」の二つの設計変更に注目し、そこ で主要建物の和風意匠がどのようにデザインされたかを具体的に明ら かにすることで、明治宫殿に用いられた和風意匠に見られるそうした 「近代和風」としての特色について明らかにした。

まず、吹上宮殿の内謁見所に見られた「小御所」風の天井意匠は、 竣工建物では内謁見所に適用された。ここでは室内が「二重折上小組 格天井小入側が繋虹梁・化粧屋根裹天井」とされ、吹上宮殿の内 謁見所よりも実際の小御所の上段之間 (二重折上小組格天井) と庇之 間 (慗虹梁・化粧屋根裏天井)に近い形式が採用されている。内謁見 所の天井意匠は、当初からこうした「御所風」の意匠で計画されてい たわけではなく、明治 17 年 5 月頃の計画案 $\left.{ }^{30}\right)$ には、室内が「格天井 塗格縁金張付小入側が「猿頪天井」として計画されたものも見られ る。竣工建物と同じ「小御所」風の天井意匠は、明治 17 年 8 月案 ${ }^{31}$ 以降に見られるようになる (図 4) ${ }^{32}$ こととから、この意匠は儀礼空間 の規模拡大と並行して適用されたものであったことがわかる。

設計過程では、内謁見所の他に謁見所にも「二重折上小組格天井」 が計画されたことが、木工事着手直前の様子を示した平面図「第武区 各所柱敷座色分之図」33) から知られる。両者は空間の規模が大きく 異なるものの「謁見空間」という点で共通していることから、「二重 折上小組格天井」は、謁見空間において天皇の「格式」を表現するた

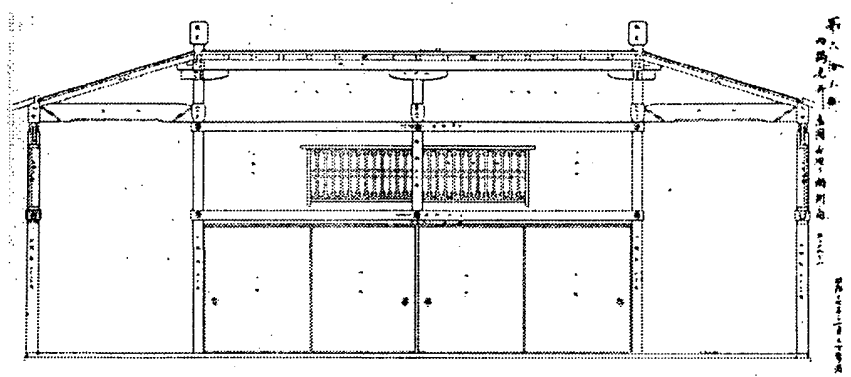

図4.内謁見所入側展開图（明治 17 年11月 22 日、木子文庫所収）
めに用いられたと考えられる。謁見所の天井は、その後の設計変更に より、最終的には装飾天井に変更されたが、木子文庫に残された複数 の天井伏図（図 5・6） 34）からは、その過程において格天井の割付が さまざまに検討された様子を知ることができる。これは、伝統的な和 風意匠である格天井を過去の日本建築には見られない大空間に適用す るにあたって、伝統的なイメージを崩さずに大空間に調和しうる適切 なスケールをさまざまに模索したものと見ることができる。

次に、壮麗化された主要建物の和風意匠について見るため、天井高 拡大前後の謁見所と饗宴所の軸部の寸法について表 2 によとめた ${ }^{35) 。 ~}$ 表 2 から、天井高の拡大に伴って有壁、小壁、内法高がそれそれ拡大 されたことが知られ、中でも小壁の高さが大幅に拡大されたことがわ かる。また、拡大後のそれそれの寸法について謁見所と篒宴所とを比 較すると、柱や長押などの部材寸法は同じであるが内法高は異なって おり、拡大後の高さ方向の寸法が木割によって決められたのではない 様子も䇲える。謁見所と䬺宴所では、拡大後の内法高さがいずれも小 壁の高さよりも約 0.75 尺高く設定されたことから、ここでは小壁の 高さよりも内法高を若干高くすることで、軸組全体の伝統的なプロ ポーションが維持されるように配虑されたと考えられる。

一方、軒高の変化について見ると、天井高が大幅に拡大されたにも 関わらず、軒高の拡大幅はいずれも1尺に留められたことがわかる。 これは、外锶立面において軒高が高くなりすき、「夕チ」の高い立面 になることを嫌ったためと考えられ、このように外観立面においても 室内の軸組意匠と同様に、伝統的な和風意匠のプロポーションを維持 しようとする姿勢を見ることができる。

室内意匠の洋風化と和風意匠との関係については、入側空間の意匠 に注目し、室内の洋風意匠と外観の和風意匠がどのように関係づけら れたかについて検討した。まず、表 2 に用いた謁見所の矩計図 (図7) を見ると、入側空間では天井高の拡大前・拡大後ともに小壁いっばい に欄間が設けられており、入側の壁面意匠は、いずれもほとんど全て が軸組と建具のみによって構成されていたと考えられる。入側建具は 当初、引違い建具で計画されていたものが設計変更によって内開き扉

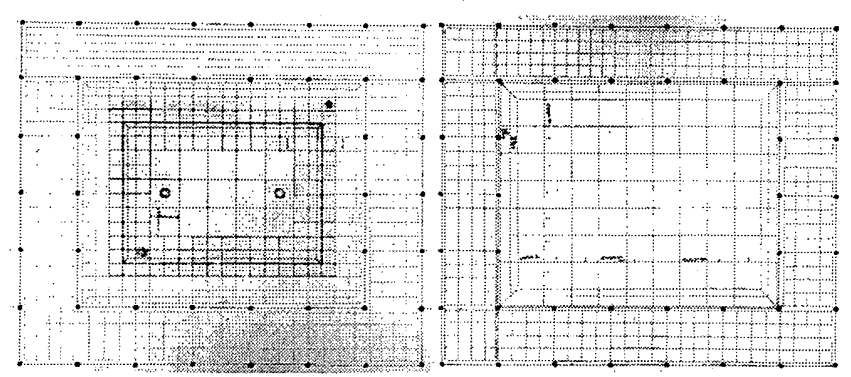

図5.謁見所天井伏図 (左: 明治 19 年 1 月 10 日、木子文庫所収)

図6.謁見所天井伏図（右：日付なし、木子文庫所収）

表 2. 謁見所 - 饗宴所の天井高拡大前後に見られる高さ方向の寸法変化

\begin{tabular}{|c|c|c|c|c|c|c|}
\hline & \multicolumn{3}{|c|}{ 箅見所 } & \multicolumn{3}{|c|}{ 宴所 } \\
\hline & 桩大前 & 桩大後。 & \multirow{2}{*}{ 增加分 } & 拡大前 & 拡大後 & \multirow{2}{*}{ 增加分 } \\
\hline & 明17.9/9 & 明18.3/12 & & 明17.9/17 & 明18.3/21 & \\
\hline $\begin{array}{c}\text { 天井高 } \\
\text { (迥龻下) }\end{array}$ & 16.6尺 & 20.37 尺 & +3.77尺 ! & 17.82尺 & $20.56 尺$ & +2.74 尺 \\
\hline$a:$ 内法高 & $7.88 R$ & $8.5 R$ & $+0.62 R$ & $8.0 R$ & $8.7 R$ & $+0.7 R$ \\
\hline b:小壁亮さ & $4.4 R$ & $7.75 \Omega$ & $+3.35 尺$ & $5.0 R$ & $7.94 R$ & $+2.94 R$ \\
\hline c : : 南壁高さ & 요 & $1.5 R$ & $+1.5 R$ & OR & $1.3 R$ & $+1.3 R$ \\
\hline b-a & $+3.48 R$ & $+0.75 \Omega$ & & $+3.0 R$ & $+0.76 尺$ & \\
\hline 入側柱太さ & 0.85 尺角 & 1.0尺角 & & $0.9 R$ 角 & 10 尺角 & \\
\hline 内法長押見付 & $0.72 R$ & $0.8 R$ & $\therefore$ & $0.72 R$ & $0.8 R$ & min \\
\hline 軒高 & $21.0 R$ & 22.0 R & +1.0 R & $22.0 R$ & $23.0 尺$ & $+1.0 尺$ \\
\hline
\end{tabular}

*内法高は、敷居上端から無目下端までの寸法 
へと変更されたことが知られるが、变更前後の柱間の展開図 ${ }^{36)}$ を比 較すると、変更後の柱間にはそれ以前にはなかった内開き扉の釣り元 を支える方立が設けられ、方立がまた欄間の同位置にも設けられたた めに、柱間がこの方立によって中央部と両脇に3分割され、伝統的な 和風意匠には見られない柱間意匠になったことがわかる（図 8)。こ うした柱間の意匠は入側空間の反対面にも適用され、また扉と欄間に 1枚ガラスが用いられたことから、入側空間は真壁でありながら極め て和風色の少ない意匠にまとめられたと見られる。一方、外観立面 （図 9）について見ると、外周部の欄間に設けられた方立はそのまま

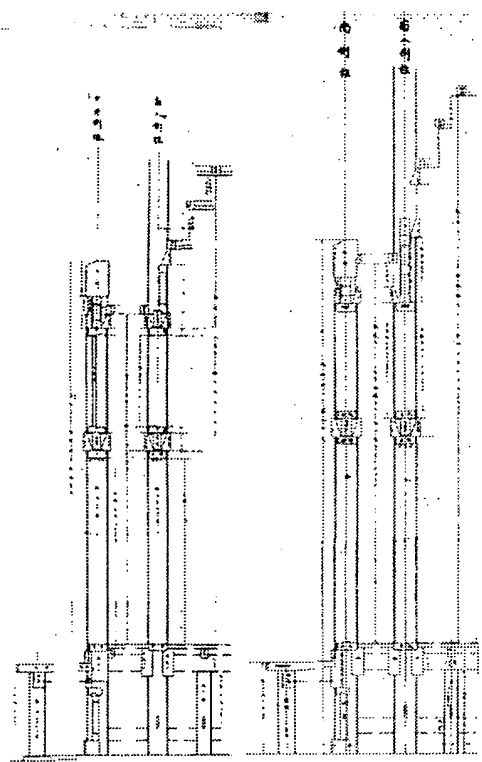

图7. 謁見所矩計图（左：明治 17 年 9 月 9 日 右：明治 18 年 3 月 12 日、同縮尺、いず れも木子文辻所収・部分）

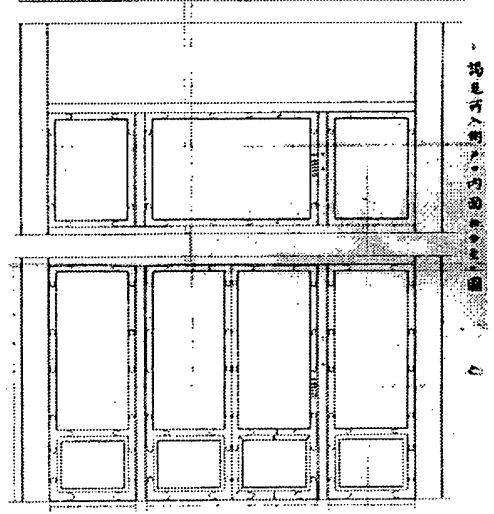

图8.「謁見所入側戸口内面」(明治 19 年 6 月 26日、木子文庫所収 ·部分）

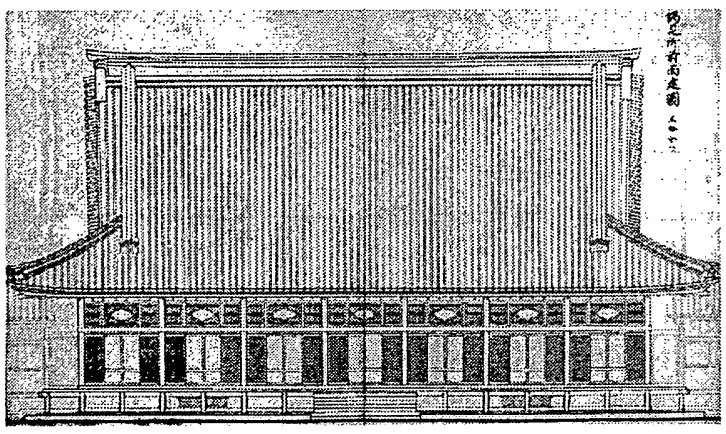

图 9. 謁見所南立面図 (宮内庁所藏『皇居御造営誌』より) 点 39) などに見ることがで きる。中でも外周部に面す
る中空の意匠形式の変更は注目すべきものと考えられ、変更前には 「木格子空」で計画されていたもの ${ }^{40)}$ か、明治 19 年 12 月の設計変更 によってほぼ全て「上ケ落シ蔀戸」に変更された ${ }^{41)}$ 。この上ケ落シ 蔀戸」は、蔀戸風にデザインされた開口部の雨戸を分銅付きの紐で上 下するように仕立てたもの ${ }^{42)}$ で、開けた時には全面開口になり、閉 めた時には外钼が部戸と同様の意匠になるものである（図 10）が、室 内側から見ると、格子がないために室内の洋風意匠と調和した横長空 のデザインになっていることがわかる（図11）。すなわち、この「上 ケ落シ蔀戸」もまた、室内の洋風意匠と外観の和風意匠とを同時に満 足させることを意図して考案されたものと考えられる。

以上のように、建設過程で加えられた「天井高の拡大」や「室内意 匠の洋風化」といった設計変更に際し、室内の軸組意匠や外観立面で は伝統的なプロポーションを維持することが重視され、また外周建具 には室内の洋風意匠にも配慮した形式のものが考案された。いずれも 伝統的な日本建築の和風意匠をそのまま用いたものではなく、近代的 な内部空間を前提に考案されたもので、近代に特有の和風意匠と見る ことができる。吹上宮殿において提案された「御所風」の意匠は、内 謁見所の天井に限って適用され、儀礼空間の室内意匠には適用されな かったが、儀礼空間においては「上ケ落シ蔀戸」や「建蔀戸」43) な どの外周建具に「御所風」をアレンジしたデザインが適用された。

\section{5. 建設過程の設計変更における設計技術者の関与の仕方}

第二章から第四章にかけて、明治 12 年以降の造営過程で計画され た木造和風の表向き建物の系譜を見てきたが、そこでは和風意匠の建 物が伝統的な「宮中儀式」との関係の下に計画され、その意匠には「御 所風」の和風意匠が繰り返し提案されるなど、設計内容においても連 続性を認めることができるものであった。こうした木造和風宮殿は、 主に宮内省の技術者によって設計されたことが知られており、中でも 実施過程については、中村一正、立川知方、樋口正峻、木子清敬といっ た主任技術者が、それぞれの担当区分に限定されずに工事全般に関 わっていたであろうと推察されている44)。本章では、中村、立川、樋 口、木子といった 4 人の上位技術者 ${ }^{45)}$ が、前章で見た設計変更にど のように関与し、あるいは関与しなかったかについて、『皇居造営録』 所收の文書に記された署名や検印跡（部・課の代表者の検印）の有無 から判断し、これら設計技術者が明治宮殿の和風意匠の創出において どのような役割を果たしたと考えられるかについて論じた。

表 3 は、表宮殿の主要建物 ${ }^{46)}$ に関する伺書（計 812 件）に記され た署名と検印跡の有無について、皇居御造営事務局が四課制.(建築課 など）に改組された明治 17 年 4 月 12 日、四部制（工業部、調查部な ど）に改組された明治19年1月16日、そして事務局が廃止され御造

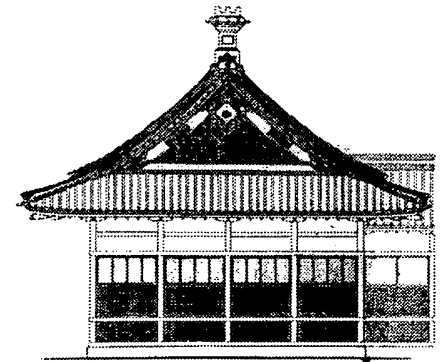

図 10. 西脱帽所南立面図（図 9 に同じ）

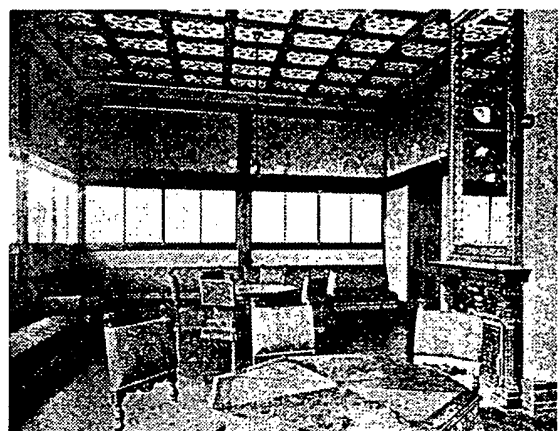

图 11. 西脱帽所内観写真 (『皇居の面影』、1963) 
営残業掛に事務が引き継がれた明治 20 年 12 月 24 日を区切りとして 集計したものである。設計監理の担当部署は、四課制においては「建 築課」四部制においては「工業部」の担当であったことが『皇居御 造営誌』に記されている47)。

まず、木子清敬について見ると、四課制の時期には検印跡が 3 件し か見られず、表宮殿の設計にはほとんど関与していなかったと考えら れる。木子清敬は、同時期の奥宮殿 (聖上常御殿・皇后宮常御殿)に 関する伺書において106件中 102件に署名が見られることから ${ }^{48)}$ 、 の時期には既に着エしていた奥宮殿の設計監理に専念していたと考え られる。一方、四部制に移行して以降は、残業掛の期間も含めてほほ 一貫して表宮殿の設計監理に関与していたことがわか。このことか ら、木子は表宮殿の設計変更において、天井高の拡大やそれに伴う和 風意匠の調整にはほとんど関与しておらず、一方、明治 20 年前後か ら竣工までに行われた室内意匠の洋風化・装飾化については、実質的 に中心的な役割を果たした可能性が高いと考えられる。

樋口正峻については、四課制の時期には 139 件中 133 件に検印跡が 見られることから、表宮殿の設計にほぼ一貫して関与していたと考え られ、特に明治 18 年においては、木工事着手直前の様子を示した平 面図「第戴区各所柱敷座色分之図」の作成された 8 月 2 日以前の伺書 42 件が全て樋口の署名で作成されている。天井高の拡大は明治 18 年 1 月頃に行われ、それに伴う和風木部の設計変更は先述の「第武区各 所柱敷座色分之図」の作成された明治 18 年 8 月 2 日はほぼ終了して いたと見られることから、この時期の設計変更とそれに伴う和風意匠 の調整には、樋口正唆が中心的な役割を果たしたと考えられる。四部 制への移行後については、樋口は「調查部」に所属していたため設計 監理に直接的に関与する立場にはなく、「調查部」としての立場から 竣工まで関与したと考えられる。

中村一正については、四課制の時期には明治 17 年のほほ全ての書 類に署名が見られるが、同時期には聖上常御殿・皇后宮常御殿の伺書 20件にも検印跡が記されており、4人の中ではただ一人、表宮殿・奥 宮殿の両方に関与していたと考えられる。明治 18 年には検印跡も全 体の半分以下に減り、特に明治 18 年 8 月以降は 52 件中 49 件に検印 跡が記されていないなど、樋口正峻と比べ、設計管理への実質的な関 与は少なかったと考えられる。中村は、四課制においては「第二区」 を担当し、四部制においても「工業部」に属するなど、公的な立場と しては一貫して表宮殿の担当となっているが、年竛的にも役職的にも 木子清敬や樋口正峻の先輩格に当たり、また開拓使の出身で洋風木造 を得意としていたことなどを考え合わせると、表宮殿の設計監理にお いては、木子や樋口の上司として携わっていた可能性も考えられる。 立川知方については、四課制の時期では明治 18 年 8 月以降の 35 件 の文書で検印跡が見られ、四部制の時期には 43 件に検印跡が見られ るが、前者はすべて中村の不在時と重なっており、後者は3件を除い て书口の不在時と重なっていることがわかる。このことから、立川は
中村や樋口の代理として検印を行った可能性が考えられ、いずれにし ても設計変更において主要な役割を果たしたとは考えにくい。

以上のように、公文書に記された署名や検印跡を見る限り、樋口正 峻は天井高の拡大とそれに伴う和風意匠の調整・変更に主要な役割を 果たし、また木子清敬は、室内意匠の装飾化・洋風化において主要な 役割を果たした可能性が高いと考えられる。このことから、これまで 不明な点が多かった樋口正峻については、表宮殿の和風大空間を創出 するにあたって極めて重要な働きをした人物として位置づけられ、ま た木子清敬については、従来の指摘 ${ }^{49)}$ 以上に和洋折哀の室内意匠の 創出に大きく寄与していたと見ることができる。木子清敬と樋口正峻 は、ともに維新前には禁裹に出仕していたことが知られている50)が、 明治宮殿に見られる近代的な和風意匠が、のような御所の伝統に通 じた設計技術者によって行われていたことも、また注目に値する。

\section{6. 結論}

本稿では、宮内庁や木子文庫所收の史料を用いて皇居の造営過程で 計画された木造和風の表向き建物の設計内容を検討し、宮殿が和風で 計画された意図やその意匠上の特徵について、以下のことを論じた。 造営過程の初期では、明治14年に宮殿が木造和風で計画された。そ の際に作成された計画案からは、宮殿を「朝儀」を行う場として位置 うける一方で、「国賓接待」のための部屋を設けないなど、宮殿の用 途を「宮中儀式」に特化しようとする姿勢が見られた。計画案では、 謁見所に京都御所の紫宸殿と極めてよく似たものが計画されたが、こ れはほぼ同時期に計画中であった京都御所の保存とそこでの「即位の 礼」の開催を考慮し、皇居において古式の「即位の礼」を行う事態を 想定して計画されたものであったと考えられる。また、この時期の計 画を巡る混乱の要因には、復古的な宮中儀式を重視する宮中関係者と 洋風の国賓接待を重視する新政府との対立もあったと考えられる。

明治 15 年の山里正殿・吹上宮殿計画では、吹上に「左右相称の御 車寄」と「大面積の内謁見所」が計画された。これは宮殿に不可欠な 内謁見所が山里正殿に計画されていないことを考慮し、伝統的な「朝 儀」に用いることも想定して吹上宮殿に計画したものと考えられる。 この内謁見所は、「二重折上小組格天井」や「化粧屋根裏天井小「部 戸」など、京都御所の「小御所」風の和風意匠で計画されたが、ほほ 同時期、同規模、同じ木子清敬の設計で建設された赤坂仮皇居・会食 所にこうした意匠が見られないことから、これらの意匠は、宮殿とし ての「格式」を表現するために適用されたと考えられる。

実施過程では、「御所」風の天井意匠が内謁見所に適用された。ま た、「天井高の拡大」や「室内意匠の洋風化」などの設計変更が加え られた儀礼空間では、伝統的なプロポーションを重視して軸組や外钼 立面が決定され、洋風意匠との調和を考虑して外钼の欄間や建具がデ ザインされた。これらは、近代的な空間特性に配慮して考案された 「近代的な和風意匠」として見ることができる。

\section{表 3.『皇居造営録』所収の「伺書」(表宮殿関係*) に見られる皇居御造営事務局上級技術者の署名と検印跡の有無}

\begin{tabular}{|c|c|c|c|c|c|c|c|c|c|c|}
\hline & & \multicolumn{4}{|c|}{ 四課制 } & \multicolumn{3}{|c|}{ 四部制。 } & \multicolumn{2}{|l|}{ 残業掛。 } \\
\hline & & \multicolumn{2}{|c|}{ 明17.4/12 明17.12 (时44件) } & \multicolumn{2}{|c|}{ 明18.1 明19.1/15 (蛙95件) } & \multicolumn{3}{|c|}{ 明19.1/16 明20.12/24 (行520件) } & \multicolumn{2}{|c|}{ 明20.12/24〜明21.10/31（計153件） } \\
\hline \multicolumn{2}{|c|}{ 検印跡の有無 } & 有（うち署名） & 無 & 有（うち署名） & 無 & & うち署名） & 無 & 有 (うち署名) & 無 \\
\hline 木子清敬 & 第一区 & $2(0)$ & 42 & $1(1)$ & 94 & 工業部 & $494(413)$ & 26 & $134(122)$ & 19 \\
\hline 桶口正峻 & 第二区 & $40(2)$ & 4. & $93(67)$ & 2 & 調查部 & $479(0)$ & 41 & $20(0)$ & 133 \\
\hline 立川知方 & 第三区 & $1(0)$ & 43 & $35(27)$ & 60 & 調査部 & $43(0)$ & 477 & $0(0)$ & 153 \\
\hline
\end{tabular}

*分析には、謁見所、饗宴所、後席之間、東西溜之間、御車寄、内謁見所、御学問所に関する同書のうち、工事葬落報告の書類を除いた合計812 件を用いた。 
公文書を見る限り、こうした設計変更においては、樋口正峻が天井 高の拡大やそれに伴う和風意匠の調整を、木子清敬が室内意匠の洋風 化を考虑した和風意匠の考案に主要な役割を果たしたと考えられる。

以上のように、皇居の造営過程は木造和風宮殿の計画案が現実的な 条件に対応しつつ具体化されて行く過程として捉え直すことができ、 そこでは、宮中儀式の伝統や「格式」を示すために京都御所がモデル にされ、また竣工建物の儀礼空間には、大空間・洋風意匠といった近 代的な空間特性に配慮した新しい和風意匠が考案されたと見られる。

註

1)従来、学術論文や一般誌において明治宮殿の造営過程を取り上げる場合は、 ほほすへてこの小野木氏の論考か参照されており、例えば村松貞次郎・近江 栄編『近代和風建案』(鹿島出版会、昭和 63 年、p.114)、初田亨「東京皇室 建築の系譜」(『東京人』平成 12 年 12 月、pp.46-51)、大川三雄「和風大邻宅 に見る近代の諸相」(『月刊文化財』平成 13 年 10 月、pp.8-15) が挙げられる。 2）天覧図は、初期案に「部省分担八境界及建築ノ图面符合スルヤ否中両省 協議ヨ遂ケ更二製図調整」したものとある。(『皇居御造営誌・巻之三』明治 14 年 1 月 11 日条)

3)阴調图』(縮尺1:800)にスケールをあてて計ったおおよその值では、「会 食所」は 8 間 $\times 10$ 間程度、「奏任控所」は 8 間 $\times 14$ 間程度と考えられる。

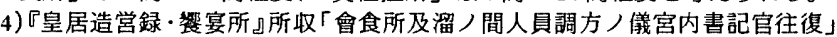
(明治 13 年 12 月 25 日、明治 14 年 1 月 17 日)、人数は式部寮の算出による。 5）『明治天皇紀』明治 14 年 1 月 1 日条および明治 14 年 11 月 3 日条

6)ここで「国賁接待」とは、晚餐会だけでなく天皇との対面をも含む広義の 概念として用いている。

7）赤坂仮皇居謁見所・会食堂と山里正殿の室名については、小野木重勝『明 治洋風宮廷建築』を参照した。なお、『下調図』に恔赤坂謁見所・会食堂移 築計画上り前に計画された木造の本丸案（明治 12 年 4 月 1 日）と西之丸案 (明治 12 年 6 月 26 日) の平面図が収録されているが、いずれも「会食堂」の 隣室に「転球室」を計画しており、国貫接待も想定していたと考えられる。 8)『皇居御造営誌・巻之三』明治 13 年 10 月 19 日条

9) 宮内庁書陵部所蔵、全 7 巻（明治 2 年 2 月 明治 21 年 1 月）

10）『皇居御造営誌・巻之四』所収「皇居御造営二付地理建物位置等二係ル意 見 7 上申又」（明治 14 年 11 月 24 日）

11）岩會具視は明治 11 年に、皇位継承に関する制度を調查する「儀制調查局」 の設置を奏請している。(『岩倉公実記』（下、明治 39 年）所収「具視儀制調 查局設監ノ議 $ᄏ$ 内閣二提出スル事」明治 11 年 3 月、pp.1575-1579)

12）『明治天皇紀』明治 11 年 10 月 16 日条

13) 『岩倉公実記』所収 $「$ 具視京都皇宮保存二関シ意見書 年 1月、pp.2038-2045)

14）『保古我呂比佐佐木高行日記』（東京大学出版会、1976）所収、柳原前光 書簡（明治 13 年 1 月 21 日付, p. 21)

15）「吉井ハ工部少輔ニシテ已二皇居建築主任トナリタル故二時々面謁下問ノ 事モアルヘシ」(「古稀之記」『元田永孚文書』第 1 巻所収、p.198) とある。 16）第一次の条約改正予議会は、明治 15 年 1 月 25 日から同年 7 月 27 日までで、 合計 21 回開かれた。

17）宮内庁所蔵『長崎省吾手記寫』（大正 12年 2 月 1 日）に、「明治十三年外務 省ヨり宮内省二轉任シタル當時恰モ條約改正ノ初歩二際シ时ノ外務卿井上閣 下ノ意見二依リ帝室二於カセラレテモ外交官接待ノ途ヨ開カセラレ度卜ノ事

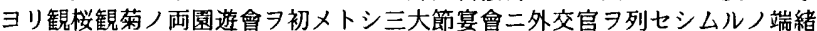
ヨ開キ又八外交官団体ノ新年拝賀 務ラ擔當シタリ」とある。長崎省吾は、明治 7 年頃に英国公使館に勤務して 皇室制度や国際儀礼を調査し、明治 13 年の帰国徭に宮内省に勤務している。

18）『保古飛呂比佐佐木高行日記』（先揭）、明治 14 年 1 月 1 日、明治 14 年 2 月7日 (柳原前光書簡) なと

19）『世外井上公伝』第 3 巻（原書房、昭和 43 年、pp.104-105）

20）平面計画の分析には、第 29 号〜第 33 号、第 46 号、第 48 号、第 52 号、第 54 号、第 57 号、第 60 号、第 65 号、第 66 号の平面图 13 点を用いた。

21)『皇居御造営誌・巻之五』(明治 16 年 1 月 13 日条) には、「監事」の䕙掌に ついて「工事経営ノ始終其他諸般ノ事７調査スル事」と記されており、皇居 御造営事務局は実施を想定した体制人と変更されたと考えられる。

22）「御三間」は京都御所において聖上常御殿に唯接して設けられ、幕末には 内謁見に使用されていたことか、藤岡通夫『京都御所 [新訂]』(中央公論美 術出版）に記されている(p.14)。

23)『明治天皇紀』明治 14 年10月10日条

24）吹上宮殿の内謁見所（99帖）の考察には、宮内庁所藏「最終案」の他に、 木子文庫所收の平面図（木100-1-002、日付なし）、立面図（木086-1-007、日 付なし)、矩計図（木081-2-008、日付なし）、屋根伏図（木 108-3-024、日付 なし)、小屋組図（木 100-2-009、日付なし）、「吹上木製御建坪等訳書」(木 108-3-009-4、明治 15 年 12 月 29 日）を用いた。いずれも图面の内容から99 帖間の内謁見所と判断したか、平面図と屋根伏龱は『下調図』との比較から 10 月案と判断でき、天井は「化粧屋根裹」と 12 月案と異なっている。よっ て、高さ方向についてもこの間に変更された可能性はありうる。

25）赤坂仮皇居会食所の規模・意匠については、宮内庁所葴『会食所新筑工事
録』(内匠寮、明治 14 年) 所収「御会食所新築大工仕様」記載の寸法を用い た。会食所の竣工時の意匠的特徵については、山崎鯛介・藤岡洋保「赤坂仮 皇居会食所の竣工時の意匠と建設の意図」(『日本建築学会大会学術講演梗概 集 (北陸)』2002、pp.241-242) にて論した。

26）吹上宮殿の明治 15 年 10 月〜 12月案では、御車寄から内謁見所、御学問 所、控室なとに至る主要な廊下の天井も「化粧屋根毫」で計画されている。 27) 木子清敬が赤坂仮皇居会食所の設計に関与していたことは、「木子家略歷」 （木子清忠『ある工匠家の記録』昭和 63 年、p.38）により判明する。また木 子清敬が吹上宮殿計画の内謁見所の設計に関与していたことは、木子文庫所 収の平面図2枚（木100-1-002、木 100-1-007）に「木子清敬」の印が見られ ることから判断した。

28）『明治天皇紀』明治 14 年 1 月 5 日条

29) P皇居御造営誌・巻之六』明治 16 年 4 月 14 日条

30) 『皇居造営録・御学問所』所収「内謁見所及廊下共百分一地八間図」(明治 17 年 5 月 7 日)

31）木子文車所収、「内謁見所地繪四」（木 100-2-002、明治 17 年 8 月 11 .日）

32）木子文庫所収、「内謁見所御間外廻り南側之図」(木100-2-048、明治 17 年 11 月 22 日)

33）『皇居造営録・謁見所』所收「第戴区各所柱敷座色分之図」（明治 18 年 8 月 2日）

34）木子文庫所收、謁見所天井伏図（図 5 : 木100-2-056、明治 19 年 1 月 10 日）、 同前（図 6:木 100-2-058、日付なし）の他に、比較的実施案に近い天井伏図 (木099-2-015-2、明治 19 年 4 月 11 日) が 1 案存在する。

35）表2に用いた矩計図はいずれも木子文庫所収で、謁見所には[木100-2-030 明治 17 年 9 月 9 日、木 $100-2-031 \cdot$ 明治 18 年 3 月 12 日]、啮宴所には [木 099 . 1-069・明治 17 年 9 月 17 日、木 $107-1-026$ ・明治 18 年 3 月 21 日]を用いた。

36）謁見所の展開図（いずれも木子文庫所収）として、変更前には「謁見所入 側内面」(木099-2-028、明治 18 年 8 月 4 日)、変更後には「謁見所入倒户口 内面」（図 8、木099-2-001-11、明治 19 年 6月 26 日）が存在する。

37) 『皇居造営録・後席之間』所収「後席之間建具檜造塗開戸及ヨサ閵間共仕 様書」(明治 20 年 7月) に「海臼」とある。欄間の繰り形は少なくとも設計 過程で3案（州浜形など）検討されたことか、木子文庫所収「謁見所外側才 サ、マ拾分壱ノ四」(木092-4-027-11、明治19年9月18日）などからわかる。 38）『皇居造営録・御車寄』所收「御車寄謁見所其外御間内模槏伺之件」(明治 17 年 4 月 16 日）の附図では、御車寄、東西脱帽所、回廊の床什上げが「敷 物」とされているのに対し、『皇居造営録・御車寄』所收「表受附之間寄木 張仕梯書」(明治 20 年 4 月) および「表受附八間廊下及東西脱帽所庭下共寄 木張仕様畫」(明治 20 年 4 月) では床仕上げから寄木張」に変更されている。

39)『皇居造営録・御車寄』所収「御車寄及受附之間果西廊下築造仕様書」(明 治 17 年 10 月) では、「幅六七寸靴捍板」と記されていたが、皇居造営録 御車寄』所收「御車寄東西之間及東西脱帽所棵造靴揌板御模槏替仕增受负申 付伺」附図「廊下通靴摺正寸之図」(明治 20 年 3 月 15 日) では、成 8 寸で上 下に繰形の付いた断面に変更されている。

40）皇居造営録・御車寄』所収「御車寄謁見所其外御間内模様伺之件」(明治 17 年 4 月 16 日) の附图には「木格子マドカラスセウシ」と記入されている。

41）『皇居造営録・御車寄』所收「御車寄及東西脱帽之間東車寄東溜少之間其 他中空蔀戸及腰長押下蔀羽目共模様替仕様書」(明治 20 年 1 月) および附図 「御車寄東西脱帽之間東溜之間大工方模様替図」(明治 19 年 12 月）より。

42）同上「東溜之間東車寄受附左右中葖上ケ落シ郘戸五分壹之図」より。

43）「筑造仕法書」(明治 18 年 6・7 月) では、謁見所の外周建具み「建郖戸」 で計画され、裚宴所と後席之間は「舞良戸」で計画されていたか、『皇居造

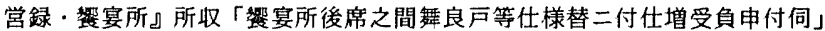
（明治 20 年 6 月 10 日）により、謁見所と同し「建蔀戸」に変更された。

44）小野木重勝『明治洋風宮廷建築』（先揭、pp.30-31）参照。実施過程におけ る木子清敬の関与の仕方については、藤岡洋保、斎藤雅子、稲葉信子「東京 都立中央図書館木子文庫所蔵の明治宮殿設計図畫に関する研究」(『日本建策 学会計画系論文報告集』第 431 号、pp.137-146) に詳しい。なお、同論文て 不明とされていた「正」の田（木子清敬の107件より多い113件）は、樋口 正㻐の旷であったことか、今回『皇居造営録』の何害から確認できた。

45）中村一正（1835～1888 頃）の経歴については、遠藤明久「森山武光と中 村一正」(『日本建築学会論文報告集』第 104 号、昭和 39 年 10 月) に詳しく、 樋口正峻（1839年～没年不群）の経歴については、小野木重勝「豊川稲荷本 殿と設計者」(『日本建築学会大会学術講演梗概集（関東）小昭和63年10月、 pp785-786) に詳しい。立川知方（1825～1894）の経歷については、土崎紀 子・沢良子編『建築人物群像』(住まい学体系065、住まいの図書館出版局、 1995）巻末資料編（p.78）を参照した。

46）分析に用いた表宮殿の建物は、謁見所、慜宴所、後席之間、東西溜之間、 御車寄、内謁見所、御学問所とした。また「侗書」のうち、工事着落の報告 書類である「工事着手上申」と「工事落成上申」は分析の対象外とした。

47）四課制に捛ける「建築課長」の職掌については『皇居御造営誌・巻之六』 (明治 17 年 5 月 26 日条) を参照し、四部制における「工業部」の職掌につい ては、『皇居御造営誌・巻之七』(明治 19 年 1 月 16 日条) を参照した。

48）聖上常御殿と皇后宮常御殿の「伺畫」合計 293 点を用いた。

49）「表・蛆宮殿とも骨格となる建築の木割や構造等の設計にあたっては木子 がかなりの部分で責任を免っていたものと推定する」(稲葉信子『木子清敬 と明治 20 年代の日本建築学に関する研究及、p.49）なと。

50) 稲葉信子『木子清敬と明治 20 年代の日本建築学に関する研究』(pp.23-24) および小野木重勝「豊川稲荷本殿と設計者」(p.786) 参照。 